\title{
A Multiple Full Mediating Effect in a PLS Hierarchical Component Model: Application to the Collaborative Public Management
}

\author{
Minerva Martínez Avila ${ }^{1, *}$, Juan José García-Machado ${ }^{2} \mathbb{D}$ and Eréndira Fierro Moreno ${ }^{1}$ \\ 1 Faculty of Accounting and Administration, Autonomous University of the State of Mexico, Toluca CP 50000, \\ Mexico; efierrom@uamex.mx \\ 2 Department of Financial Economics, Accounting and Operations Management, University of Huelva, \\ 21071 Huelva, Spain; machado@uhu.es \\ * Correspondence: 33mmartineza@gmail.com or mmartineza@uamemx.mx; Tel.: +52-722-3906204
}

check for updates

Citation: Martínez Avila, M.; García-Machado, J.J.; Fierro Moreno, E. A Multiple Full Mediating Effect in a PLS Hierarchical Component Model: Application to the Collaborative Public Management. Mathematics 2021, 9, 1910 https://doi.org/10.3390 /math9161910

Academic Editor:

Octavian Dospinescu

Received: 30 June 2021

Accepted: 31 July 2021

Published: 11 August 2021

Publisher's Note: MDPI stays neutral with regard to jurisdictional claims in published maps and institutional affiliations.

Copyright: (c) 2021 by the authors. Licensee MDPI, Basel, Switzerland. This article is an open access article distributed under the terms and conditions of the Creative Commons Attribution (CC BY) license (https:// creativecommons.org/licenses/by/ $4.0 /)$.

\begin{abstract}
The objective of this article was to determine the mediating effect of shared knowledge and organisational commitment in the relationship between organisational values and collaborative public management. Organisational values are also made up as a second-order construct consisting of other first order sub-dimensions such as authority, autonomy, conservatism, equality, harmony, and hierarchy. This research is based both on the Theory of Resources and Capacities and the theoretical perspective based on knowledge. The hypotheses proposed were supported with the use of structural equation models based on composites (PLS-SEM). The results show empirical evidence of a multiple fully mediating effect. The findings confirmed that organisational values do not have a significant direct positive impact on collaborative public management unless they are full mediated by shared knowledge and organisational commitment. In addition, this research framework is effective for improving public employees' work efficiency and has practical implications for scholars, practitioners, and the authorities.
\end{abstract}

Keywords: collaborative public management; shared knowledge; organisational commitment; PLS-SEM; hierarchical component models

\section{Introduction}

In modern economic landscapes, public management networks are coming to the forefront as a way of creating value collectively rather than as individual organisation. This tendency can be summarised as doing away with barriers and enhancing collaboration. At times, this may even be true for competitors, given the fact that one organisation may not have enough resources at its disposal to be able to continue in an ever more competitive market. For this reason, organisations come together and share resources in order to become more effective and efficient and, consequently, become or remain competitive. Globalisation and technology have fermented interdependence between organisations, breaking down barriers and promoting collaboration [1]. Collaboration refers to any shared activity between two or more organisations, working together to create public value collectively, rather than individually [2].

The challenges that public-sector organisations face are ever more complicated and include different sorts of social problems and even challenges which may transcend borders due to a lack of resources. Citizen-centred collaborative public management is a way of circumnavigating a lack of resources and dealing with social problems collectively. The exchange of knowledge and information between public figures and leaders is based on mutual trust and support [3].

In the review of the literature, little empirical evidence was found on the study of collaborative public management or on the arguments concerning its rationale so that the 
present investigation is an area of opportunity that can contribute to the debate on this type of management of public organisations. Collaborative public management has been studied under a strategic resources approach that allows for better organisational efficiency and effectiveness. Under this assumption, this research used the theoretical perspective of resources and capabilities [4-6] and, specifically, the perspective which understands the organisation as a repository of knowledge, which can be generated and applied by that organisation [7-9] and where the resources linked to the knowledge of the organisation are the first drives of organisational efficiency [6]. Under these arguments and theoretical axis, the following research questions arise:

First question:

What is the extent to which organisational values are associated with collaborative public management?

Second question:

What is the extent to which the relationship between organisational values and collaborative public management is mediated by shared knowledge and organisational commitment?

Collaborative public management is a type of management focused on shared resources and abilities, which works ultimately for the benefit of local citizens and marginalised communities in the State of Mexico. It is commonly believed that the resources which the state and municipal level government have at their disposal flow more freely in urban areas. In rural communities, however, the lack of resources is evident. This affects institutional management and, above all, citizens. Nonetheless, public management in these communities is a much bigger challenge. Therefore, studying this type of collaborative public management through the lens of values, shared knowledge, and organisational engagement is beneficial to our understanding of strategy development and implementation, as well as of collaboration policies. This, to a certain extent, improves public sector management.

The fundamental purpose of this research was to determine the mediating effect of shared knowledge and organisational commitment in the relationship between organisational values and collaborative public management. Public management is related to the very values of organisations $[10,11]$. This research provides a contribution to scientific knowledge through a theoretical model that supports the effect of mediating latent variables of shared knowledge and organisational commitment on collaborative public management (theoretical contribution). In addition, there is a gap in the scientific research dealing with the limiting factors and the contingency variables that affect the strategies of organisations in emerging economies [12-14]. Other aims include carrying out an explanatory and confirmatory hierarchical component model (HCM) based on a PLS-SEM approach and checking which type of HCM it corresponds to by means of a confirmatory tetrad analysis (CTA-PLS). A self-administered questionnaire was applied to public sector organisations in Mexico in the second half of 2019-the sample consisted of 110 civil servants working in the municipal government (36\%), the government of the State of Mexico $(39 \%)$, and the federal government $(25 \%)$. One of the characteristics of the sample was that the units of analysis shared certain characteristics, as they belonged to different public organisations, such as geographic proximity and a similar organisational context.

The rest of the study is organised as follows. Firstly, the literature was reviewed in order to support the research. Secondly, the research methodology is described, and the results are presented. Finally, this study ends with the conclusions and discussion, highlighting the theoretical contribution, practical implications, limitations, and suggestions for future research.

\section{Theoretical Framework}

The theoretical pillars of this study are based on the Theory of Resources and Capacities and on the knowledge-based approach. The resource-based perspective holds that performance, organisational effectiveness, and sustainable competitive advantage stem from the potential of resources and capabilities $[4,5,15,16]$. On the other hand, the emerging view of the knowledge-based theory considers organisations as heterogeneous 
knowledge carrier entities, where knowledge is the most valuable resource through which organisations create additional value, with the addition of presenting a new perspective for the management of alliances in organisations [17], which is one of the purposes of collaborative public management. New thinking in public administration focuses chiefly on competence, particularly so when collaboration between organisations is aimed at the challenges faced by modern society in order to develop value propositions $[18,19]$.

Collaborative public management

The theoretical bases to understand the new management are not based on the traditional public administration, which is based on two theories: the theory of the bureaucracy and the theory of the separation between politicians and administrators, rather, the new public management under the theoretical bases of the economy and private management [20]. The New Public Management (NPM) refers to a series of novel approaches to public administration and management that emerged in a number of OECD countries in the 1980s. The NPM model arose in reaction to the limitations of the old public administration in adjusting to the demands of a competitive market economy ([21], p. 7) Similarly, Raczkowski [22] argues that public management is investigated on the theoretical basis of a new institutional economy. Therefore, the research phenomenon was based on theoretical perspectives: the Theory of Resources and Capacities and on the knowledge-based approach.

At the end of the 1990s, new nomenclatures emerged in the field of public management: new public management, network management, and collaborative public management [23]. In recent years, however, a new form of public management is required, where the most important change in administrative functioning implies the interdependence and collaboration between public organisations [24], that is, through organisational strategies in the public sector that lead to an efficient administrative functioning of a public management that gives response and attends to the social, political, and economic spaces $[25,26]$. Collaborative public management is a process of multi-organisational agreements that focuses attention on problems that cannot be solved simply by individual organisations, but through organisational collaborative work, in order to achieve common objectives in multi-sectoral relationships by means of the value of reciprocity [24,27].

Ansell and Gash [28] consider that collaborative public management is a government agreement to work in a collective decision-making process that aims to establish, implement, or administer public policies. On the other hand, Agranoff et al. [29] conceived of collaborative public management as a process of assistance and management of multiorganisational agreements to solve problems that an organisation could not easily solve on its own. However, from the point of view of Kapucu et al. [30], collaborative public management has a more local approach and focuses on practical collaboration to solve social problems and achieve community objectives at an organisational level.

Organisational values

Although organisational values have been studied for decades, the research on their role in organisations continues to expand at an increasing pace [31,32]. Organisational values are a source of organisational strength and a central element of organisational culture $[33,34]$. These are not static and are susceptible to change and serve as a guide to lead the behaviour of employees by replacing several rules and procedures. Therefore, large organisational changes cannot be executed without a reconsideration of values, given that there are some existing cases where individuals are inspired by these values to achieve goals. Organisational values have become the cornerstone that will lead to the improved performance of an organisation [35]. Thus, productive and healthy organisations have strong organisational values as part of their philosophy [36]. Although each member of the organisation has their own personal values that make them unique, organisations have common values that guide the performance of their collaborators. Akinsorotan and Oladele [37] argue that workers who share organisational values with their colleagues work better and therefore show a managerial improvement. 
Porto and Ferreira [38] explain organisational values through six dimensions: harmony, autonomy, authority, conservatism, equality, and hierarchy. Harmony is a fundamental value derived from Confucianism, and encompasses a state of mind, a process of action, and the results of action [39]. Autonomy is a central value where autonomous people are often in the best position to determine what would be good or bad for them when making a certain decision [40]. Authority, according to Weber, is based on the belief in the legality of the rules and the rights of those who are invested with authority to issue orders under rules and implies obedience to a legally established impersonal order [41]. Conservatism is a conservative action of fidelity, regarding customs and obedience of organisational norms. Equality is a value that the organisation postulates to the collaborators and indicates fairness of opportunities for everyone involved in the work, while the value of hierarchy emphasises the decision-making process and the centralisation of power [38].

Shared Knowledge

Knowledge is the most valuable resource for organisations, owing to the fact that it is a source of a competitive advantage. For instance, the best Japanese companies administer knowledge in companies and R\&D laboratories. These modern organisations value knowledge and knowledge transfer as key centres of creation [42]. Perhaps many organisations which possess strategically established practices for knowledge management acquire it by sharing knowledge between company employees. However, the source of this knowledge may also be external.

Knowledge sharing requires the goodwill of one group or individual to collaborate with another in order to obtain a mutual benefit. However, although knowledge sharing is beneficial to the organisation, company directors must still identify sources of tacit and explicit knowledge. Tacit knowledge is sometimes hard to identify because it resides in each of us. Therefore, in the field of collaborative public administration, these two varieties of knowledge must be identified in order for them be shared withing the organisation. In order that administration in public organisations be efficient, new approaches are required. For instance, knowledge management and knowledge sharing are strategies for creating and integrating knowledge-management processes. These can lead to new ways of solving problems associated with collaborative administration.

Organisational Commitment

Organisational commitment is focused on creating and accepting the objectives and values of an organisation and is observed in the organisation's results and interests. This can be shown by way of the fondness, positive attitudes, and feelings of employees towards the organisation.

Furthermore, organisational commitment is observed when a subordinate identifies himself or herself with the company mission. Employees must feel that they belong to their organisation and be willing to contribute to the company by going beyond their quotidian assigned activities [43]. Barron and Chou [44] consider that employee commitment is an indicator of work efficiency and performance. Choi and Col [45] consider that organisational commitment is achieved when an employee accepts the values, mission, vision, and objectives of the company. The employee must be willing to work in the name of the company's achievement. In this sense, organisational commitment can be understood as the employees' conviction to belong to the organisation, identify with the organisation, and contribute to the organisation.

\subsection{The Effect of Organisational Values on Collaborative Public Management}

Organisational values are a source of organisational strength and a central element of organisational culture $[33,34]$. These are not static, and are susceptible to change and serve as a guide to lead the behaviour of employees by replacing several rules and procedures. Therefore, large organisational changes cannot be executed without a reconsideration of values, given that there are some existing cases where individuals are inspired by these values to achieve goals. Organisational values have become the cornerstone that will lead to the improved performance of an organisation [35]. 
Organisational values improve effectiveness and goal achievements in public management. Additionally, organisational values can be a determining factor for organisational success, given the fact that they act as a strong foundation for guiding employee engagement and behaviour. This is only true when the values are in alignment with the organisation itself [35]. Public managers must have certain personal qualities; however, this is often easier said than done. Nevertheless, in the field of public management there is a long history of evaluating efficiency through so-called "efficiency criteria" [46]. Bureaucratic values lead to efficiency and effectiveness, and they are guidelines for decision making, like a moral compass which emerges from an organisational culture in which members have a clear idea of what value-based public management means [47].

For this reason, organisational values play an important role in public organisations, and they are seen as desirable for thought and action processes [48]. Bansal [49] sees the sharing of organisational values as relevant, strategic, and necessary in order to achieve institutional aims. This part of organisational culture has been described as the shared values which are the foundations of a social system. Therefore, organisational values are the cornerstone of public management as part of organisational culture. It is expected that these values will have a positive impact on collaborative public management. This is considered to be a process of multi-organisational agreements that focuses attention on problems that cannot be solved simply by individual organisations, but through organisational collaborative work, in order to achieve common objectives in multi-sectoral relationships by means of the value of reciprocity $[24,27]$.

Organisational values are intertwined with organisational management and play a key role in the creation of an organisation's plans and in all its decisions, as part of a public management model, in order to achieve its objectives and improve its management effectiveness [50]. Therefore, organisational values play an important role in the functioning of organisations: in productivity, performance, success, and commitment at work [51,52]. Thus, organisational values have become the cornerstone that leads to an improvement in overall effectiveness and organisational performance [50]. According to these arguments, the first research hypothesis is proposed as the following:

Hypotheses 1 (H1). Organisational values have a positive impact on collaborative public management.

\subsection{The Mediating Effect of Shared Knowledge and Organisational Commitment in the Relationship between Organisational Values and Collaborative Public Management}

In organisations, knowledge has become the most important factor [42,53,54], and it is an essential resource in value creation [55]. Therefore, it implies the need to generate, apply, and transfer new forms of knowledge in public sector organisations in order to make them more efficient. The effectiveness in the management of public organisations requires new approaches to address matters of public interest. Technology and the sharing of knowledge are of help, but at the same time, they force government agencies to share information in an integrating and inter-operational way and to generate integral processes of knowledge management, which can lead to new ways of solving problems in a collaborative manner in decision making and action [56].

Therefore, public management requires knowledge management [57-60] in order to conduct strategic actions and guide the efforts in the process of the generation and exchange of knowledge in organisations [61-63], as well as to increase organisational commitment $[64,65]$. This leads to the development of improved attitudinal actions in public workers and the achievement of greater efficiency and effectiveness in public organisations. In parallel with this, organisational values act as a central dimension of organisational management, performance, and productivity $[50,51,66]$.

Values are essential in public administration in so far as they work to benefit citizens and they guide administrative actions to be more efficient and effective $[67,68]$. The aforementioned values of public administration are manifested in attitudes, preferences, 
decision making, and actions [69]. In turn, values lead to organisational commitment as a source of beliefs in and acceptance of company objectives. Furthermore, values play an important role in commitment. If one's values coincide with those of the organisation, he or she will be more committed to them [66]. Organisational commitment impacts on the way an organisation is managed through collaborative effort which requires structures and processes for the interchange of information. Administration requires knowledge sharing to facilitate interorganisational management [70]. Among the main activities of public sector organisations is to create and provide knowledge to collaborators [71]. In this way, new knowledge-management processes can be created and integrated, which can lead to new ways of solving problems associate with collaborative organisation [56].

Some studies present empirical evidence of organisational values and their positive effect on management, organisational commitment, and shared knowledge [65,72,73]. Hence, in a changing environment, shared knowledge will endure the competitive demands of the organisation and improve the cohesion between employees, their loyalty, and even their willingness to share knowledge in such a way that, when the employees are committed, they are capable of identifying themselves with the objectives and values of the organisation and will be willing to contribute to the organisational management program [74]. According to the literature, knowledge management and shared knowledge are jointly considered as mediating latent variables in social interaction and innovating performance, participatory decision-making, transformational leadership, and in organisational performance $[75,76]$. On the other hand, recent studies provide evidence for the fact that organisational engagement mediates the relationship between organisational culture that includes organisational values and performance [77].

Therefore, organisational values are intangible resources and can have an impact on collaborative public management through shared knowledge and organisational commitment.

On the basis of this theoretical and empirical discussion, we postulate the following mediation hypotheses:

Hypotheses 2 (H2). Shared knowledge positively mediates the relationship between organisational values and collaborative public management.

Hypotheses 3 (H3). Organisational commitment positively mediates the relationship between organisational values and collaborative public management.

Figure 1 shows graphically the multiple mediating hierarchical model proposed in this research.

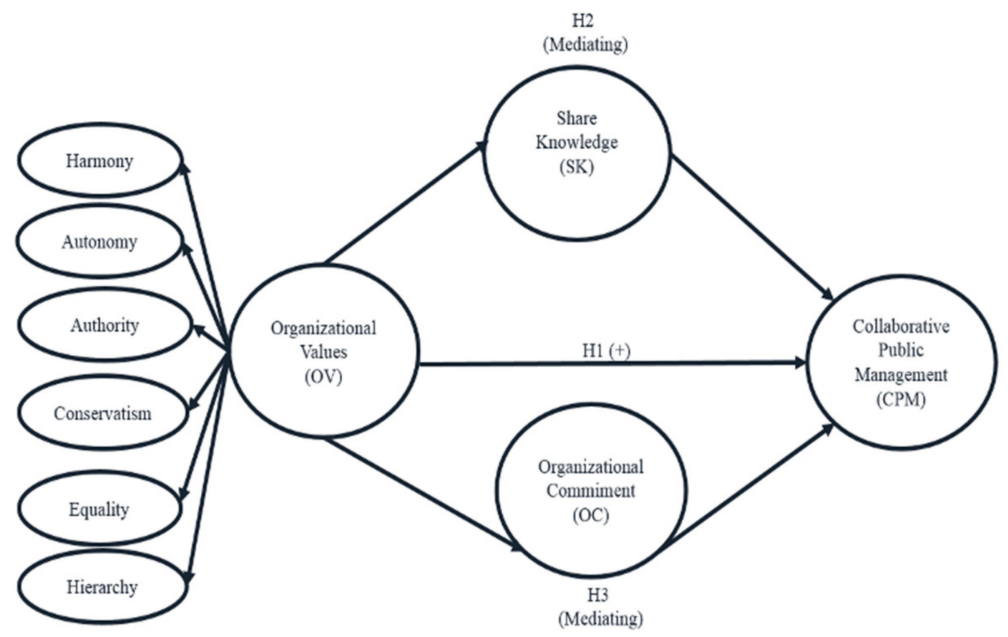

Figure 1. Research model and hypotheses. 


\section{Methodology and Data Analysis}

A quantitative approach was selected to test the relationships between constructs and mediation, with a non-experimental cross-sectional research design, with a sample size of 110 , and the analysis units were public sector organisations.

\subsection{Data Collection}

In order for volunteer bias to be avoided, volunteers should be similar to the rest of the population in most ways [78]. Additionally, the questionnaire has clearly defined aims and, for this reason, when a self-evaluated questionnaire is an appropriate tool, it can be a source of high-quality data [79]. Therefore, a self-administered questionnaire was applied to public sector organisations in Mexico in the second half of 2019-the sample consisted of 110 public employees of the municipal government (36\%), the government of the State of Mexico (39\%), and the federal government (25\%). These units of analysis were selected because they had certain similar characteristics owing to the fact that they belong to different public organisations. These similarities are geographical proximity, work positions, and organisational context.

To determine the minimum required sample size, we based this study on the recommendations of Nitzl [80]. That is to say, for a statistical power of $80 \%$, six predictors, a medium effect size of 0.15 , and a significance level of 0.05 , a size of 98 is recommended.

The sample profile of respondents revealed that $50.6 \%$ were male and $49.4 \%$ female. Regarding job positions and labour hierarchy, the highest percentage corresponded to $47.5 \%$ (administrative staff), $44.5 \%$ middle managers and executives, and $8 \%$ advisors at staff level in relation to scholarship or educational level; most of them had a bachelor's degree $(65.5 \%), 20.9 \%$ revealed they were specialists or with a high school diploma, and $13.6 \%$ had studied at the postgraduate level.

\subsection{Measures and Operationalisation of the Constructs}

Data collection items were adapted from the theoretical contributions of several authors [38,81-83]. The study used the technique of translation into Spanish and adaptation to the Mexican context. The exogenous latent variable of "organisational values" was based on Porto and Ferreira [38] and is composed of six dimensions: authority, autonomy, conservatism, equality, harmony, and hierarchy. The construct "organisational commitment" was based on Allen and Meller [83]. "Share knowledge" was built on the theoretical basis of Lin [81], and "collaborative public management" was based on Thomson et al. [82]. All items were measured on a seven-point Likert scale from 1 "totally disagree" to 7 "totally agree".

The organisational values construct was operationalised as mode A reflective-reflective higher-order construct (HOC), comprising six dimensions: authority was classified into three items, autonomy into four items, conservatism into four items, equality into four items, harmony into four items, and hierarchy into two items. The remaining constructs were operationalised as mode A lower-order constructs (LOCs). Organisational engagement was measured through seven items. Shared knowledge was measured through six items and, finally, collaborative public management was measured through six items.

\subsection{PLS Analysis}

This study used partial least squares structural equation modelling (PLS-SEM) [84] for the analysis of data, which is a second-generation statistical technique, mainly focusing on complex, sophisticated, and useful models for working with composites, which contain reflective and formative measurement models of constructs [85-89]. This technique of modelling structural equations on the basis of the variance [90-96] applies a series of regressions based on ordinary least squares (OLS) that estimate the parameters of the model so that they maximise the explained variance $\left(R^{2}\right)$ of the endogenous constructs [97].

This research shows a model of reflective-reflective hierarchical component (type I $\mathrm{HCM}$ ), which indicates that the model was operationalised with one-dimensional (first- 
order) and multidimensional constructs, also called second-order, higher order, or hierarchical components [98].

In a reflective measurement model, the causality relationship goes from the construct to the indicators, which indicates that the construct causes its indicators, which can be interchangeable. Therefore, a change in the latent variable is reflected or manifested in its indicators [94,99-101].

Firstly, to ensure a correct specification of the measurement model, we based the model on theoretical arguments. Although the conceptual and theoretical justification of an established measurement model is useful in order to avoid erroneous specification and to keep it clear from an incorrect assessment of the relationships in the partial least squares modelling [99,102], it was also convenient to conduct a confirmatory tetrad analysis (CTA-PLS) that empirically allows us to evaluate if the specification of an adopted measurement model based on the theoretical foundations is also supported by the data [103]. In accordance with measurement theory (a theory for determining how to measure latent variables or constructs) and its validation through the confirmatory tetrad analysis, we needed to evaluate the research model as a reflective-reflective model rather than a formative model. In this sense, when we ran the CTA-PLS procedure, the results allowed us to confirm that there was empirical support for the classification of the model as a reflective measurement model. This is based on our results and in line with the decision rules outlined by Jarvis et al. [104].

On the other hand, to estimate the second-order higher construct, we carried out a two-step approach, which is a method that uses the scores of the latent variables. In the first step, the scores of the latent variables, within the first-order constructs, are obtained. In the second stage, these scores serve as manifest variables of the second order constructs $[98,100]$.

Specifically, the construct of "organisational values" is considered a second-order composite of reflective type or Mode A (HOC). Regarding the constructs "organisational commitment", "shared knowledge", and "collaborative public management", they are all first-order constructs and are measured as reflective types (LOCs).

\section{Results}

Once the research model was structured, we applied the methodology proposed by Henseler et al. [68] and Albort-Morant et al. [105].

\subsection{Evaluation of the Global Model Fit}

To evaluate the global model fit, we ran a bootstrapping procedure and firstly analysed the SRMR (standardised root mean square residual), which is defined as the root mean square discrepancy between the observed correlations and the model-implied correlations, where a value of 0.10 for SRMR would indicate a good fit [93]. However, a value of 0.08 proposed by Hu and Bentler [106] is considered more appropriate. The model has a goodness of fit for SRMR below the threshold $<0.08$. In addition, two measures recommended by Dijkstra and Henseler [107] were also evaluated: (1) $d_{U L S}$ (unweighted least squares discrepancy) and (2) $\mathrm{d}_{\mathrm{G}}$ (geodesic discrepancy) as exact fit criteria. Table 1 shows the global fit of the confirmatory model in a suitable manner, which indicates that the results are below both percentiles: 95\% (HI95) and 99\% (HI99).

Table 1. Global model fit measures.

\begin{tabular}{ccll}
\hline Criterion & Value & HI95 & HI99 \\
\hline SRMR & 0.060 & 0.063 & 0.070 \\
\hline $\mathrm{d}_{\mathrm{USL}}$ & 0.924 & 1.010 & 1.233 \\
\hline $\mathrm{d}_{\mathrm{G}}$ & 0.562 & 0.668 & 0.772 \\
\hline
\end{tabular}

Note: standardised root mean squared residual (SRMR), unweighted least squares discrepancy $\left(\mathrm{d}_{\mathrm{USL}}\right)$, geodesic discrepancy $\left(\mathrm{d}_{\mathrm{G}}\right)$, booatstrap-based $95 \%$ percentil (HI95), bootstrap-based $99 \%$ percentil (HI99). 


\subsection{Evaluation of Measurement Models}

The purpose of the reflective measurement models is to assess the reliability and validity of the construct measurements through the reliability of internal consistency, convergent validity, and discriminant validity [94]. In order for the reliability of an individual indicator to be tested, its standardised outer loadings must be higher than 0.7 [94]. Regarding the reliability of the construct, in PLS-SEM, it is recommended that one use the composite reliability $\left(\rho_{c}\right)$, wherein our results were between the established thresholds $(0.70$ and 0.90$)$ for confirmatory research.

Table 2 shows the composite reliability $\left(\rho_{\mathrm{A}}\right)$, based on Dijkstra and Henseler [107] as the best measure for consistent reliability, although Cronbach's alpha is also presented as a traditional measure. In addition, there is evidence of convergent validity with the AVE (average variance extracted), which shows the extent by which a latent construct explains the variance of its indicators, whose established threshold is AVE > 0.5 [108]. Therefore, our measurement models show reliability, convergent validity, and discriminant validity.

Table 2. Results for reflective measurement models.

\begin{tabular}{|c|c|c|c|c|}
\hline Constructs/Indicators & Outer Loadings & $\begin{array}{c}\text { Cronbach's } \\
\text { Alpha }\end{array}$ & $\begin{array}{c}\text { Composite } \\
\text { Reliability Rho }\left(\rho_{A}\right)\end{array}$ & AVE \\
\hline \multicolumn{5}{|c|}{ Organisational Values (second-order, composite mode A) } \\
\hline \multicolumn{2}{|c|}{ Authority (first-order mode A) } & \multirow{4}{*}{0.673} & \multirow{4}{*}{0.764} & \multirow{4}{*}{0.605} \\
\hline au-1 & 0.543 & & & \\
\hline au-2 & 0.879 & & & \\
\hline au-3 & 0.864 & & & \\
\hline \multicolumn{2}{|c|}{ Harmony (first-order mode A) } & \multirow{5}{*}{0.851} & \multirow{5}{*}{0.852} & \multirow{5}{*}{0.692} \\
\hline ar-1 & 0.843 & & & \\
\hline ar-2 & 0.818 & & & \\
\hline ar-3 & 0.862 & & & \\
\hline ar-4 & 0.802 & & & \\
\hline \multicolumn{2}{|c|}{ Hierarchy (first-order mode A) } & \multirow{3}{*}{0.647} & \multirow{3}{*}{0.637} & \multirow{3}{*}{0.582} \\
\hline je-1 & 0.905 & & & \\
\hline je-2 & 0.606 & & & \\
\hline \multicolumn{2}{|c|}{ Equality (first-order mode A) } & \multirow{5}{*}{0.848} & \multirow{5}{*}{0.862} & \multirow{5}{*}{0.688} \\
\hline ig-1 & 0.730 & & & \\
\hline ig-2 & 0.867 & & & \\
\hline ig-3 & 0.876 & & & \\
\hline ig-4 & 0.835 & & & \\
\hline \multicolumn{2}{|c|}{ Conservatism (first-order mode A) } & \multirow{5}{*}{0.867} & \multirow{5}{*}{0.874} & \multirow{5}{*}{0.716} \\
\hline co-1 & 0.895 & & & \\
\hline $\mathrm{co}-2$ & 0.844 & & & \\
\hline $\mathrm{co}-3$ & 0.829 & & & \\
\hline $\mathrm{co}-4$ & 0.814 & & & \\
\hline \multicolumn{2}{|c|}{ Autonomy (first-order mode A) } & \multirow{5}{*}{0.867} & \multirow{5}{*}{0.880} & \multirow{5}{*}{0.714} \\
\hline aut-1 & 0.895 & & & \\
\hline aut-2 & 0.868 & & & \\
\hline aut-3 & 0.834 & & & \\
\hline aut-4 & 0.778 & & & \\
\hline
\end{tabular}


Table 2. Cont.

\begin{tabular}{|c|c|c|c|c|}
\hline Constructs/Indicators & Outer Loadings & $\begin{array}{l}\text { Cronbach's } \\
\text { Alpha }\end{array}$ & $\begin{array}{c}\text { Composite } \\
\text { Reliability Rho }\left(\rho_{A}\right)\end{array}$ & AVE \\
\hline \multicolumn{2}{|c|}{$\begin{array}{l}\text { Organisational Commitment (first-order } \\
\text { mode A) }\end{array}$} & \multirow{8}{*}{0.917} & \multirow{8}{*}{0.934} & \multirow{8}{*}{0.670} \\
\hline oc-1 & 0.785 & & & \\
\hline oc-2 & 0.870 & & & \\
\hline oc-3 & 0.752 & & & \\
\hline oc- 4 & 0.817 & & & \\
\hline oc-5 & 0.908 & & & \\
\hline oc- 6 & 0.815 & & & \\
\hline oc-7 & 0.773 & & & \\
\hline \multicolumn{2}{|c|}{ Shared Knowledge (first-order mode A) } & \multirow{7}{*}{0.933} & \multirow{7}{*}{0.934} & \multirow{7}{*}{0.750} \\
\hline sk-1 & 0.832 & & & \\
\hline sk-2 & 0.868 & & & \\
\hline sk-3 & 0.861 & & & \\
\hline sk-4 & 0.880 & & & \\
\hline sk-5 & 0.904 & & & \\
\hline sk-6 & 0.849 & & & \\
\hline \multicolumn{2}{|c|}{$\begin{array}{l}\text { Collaborative public management } \\
\text { (first-order mode A) }\end{array}$} & \multirow{4}{*}{0.717} & \multirow{4}{*}{0.840} & \multirow{4}{*}{0.635} \\
\hline cpm-1 & 0.729 & & & \\
\hline cpm-2 & 0.827 & & & \\
\hline cpm-3 & 0.831 & & & \\
\hline
\end{tabular}

\subsection{Discriminant Validity}

Several tests can be used to evaluate whether a construct's measures discriminate empirically: (1) cross-loadings, (2) Fornell-Larcker criterion, and (3) heterotrait-monotrait ratio (HTMT) [94], with the latter being the most recent test in the PLS context. Simulation studies conducted by Henseler et al. [109] have shown that to assess the discriminant validity, one should use the heterotrait-monotrait ratio (HTMT). An HTMT value above 0.90 suggests a lack of discriminant validity, and thus a value of 0.85 is recommended to ensure that the constructs are really distinct [94].

To estimate the HTMT, two forms can be used: the first one through correlations and the second one by running a bootstrap to evaluate the confidence interval with the bias corrected. This interval allows the testing of the null hypothesis $\left(\mathrm{H}_{0}:\right.$ HTMT $\left.\geq 1\right)$ and the alternative $\left(\mathrm{H}_{1}: \mathrm{HTMT}<1\right)$ [110]. If the value 1 is outside the confidence interval, then the constructs differ [84]. Tables 3-5 show the results of satisfactory discriminant validity through the correlations of the heterotrait-monotrait ratio (HTMT) and the FornellLarcker criterion.

Table 3. Discriminant validity (Fornell-Larcker criterion).

\begin{tabular}{ccccc}
\hline & CPM & SK & OC & OV \\
\hline CPM & 0.797 & & & \\
\hline SK & 0.533 & 0.866 & & \\
\hline OC & 0.534 & 0.660 & 0.819 & 0.806 \\
\hline OV & 0.527 & 0.742 & 0.733 &
\end{tabular}

Note: Diagonal elements are the square root of variance shared between the constructs and their measures (AVE) 
Table 4. Discriminant validity (heterotrait-monotrait ratio, HTMT).

\begin{tabular}{cccc}
\hline & CPM & SK & OC \\
\hline SK & 0.639 & & \\
\hline OC & 0.637 & 0.711 & 0.799 \\
\hline OV & 0.645 & 0.800 & \\
\hline
\end{tabular}

Table 5. Discriminant validity (HTMT): confidence interval bias corrected.

\begin{tabular}{ccccc}
\hline Constructs & Original Sample & Bias & $\mathbf{2 . 5 \%}$ & $\mathbf{9 7 . 5 \%}$ \\
\hline $\mathrm{SK} \rightarrow \mathrm{CPM}$ & 0.639 & 0.000 & 0.499 & 0.761 \\
\hline $\mathrm{OC} \longrightarrow \mathrm{CPM}$ & 0.637 & -0.002 & 0.452 & 0.772 \\
\hline $\mathrm{OC} \longrightarrow \mathrm{SK}$ & 0.711 & -0.000 & 0.601 & 0.796 \\
\hline $\mathrm{OV} \longrightarrow \mathrm{CPM}$ & 0.645 & 0.001 & 0.486 & 0.770 \\
\hline $\mathrm{OV} \longrightarrow \mathrm{SK}$ & 0.800 & 0.001 & 0.717 & 0.868 \\
\hline $\mathrm{OV} \rightarrow \mathrm{OC}$ & 0.799 & -0.002 & 0.700 & 0.870 \\
\hline
\end{tabular}

\subsection{Evaluation of the Structural Model (Hypothesis Testing)}

Once it has been confirmed that the measured constructs are reliable and valid, the next step is to assess the structural model [111]. Yet before the evaluation of the structural model, it is necessary to examine whether there are collinearity issues among latent variables. Variance inflation factor (VIF) values are all below the threshold of 3 [112]. Therefore, there are no problems of collinearity in the structural model. Assessing the structural model involves examining the predictive capabilities of the model and the relationships between the constructs. The key criteria to evaluate the structural model in PLS-SEM are the algebraic sign, the magnitude and the significance of the path coefficients, the coefficient of determination $\left(\mathrm{R}^{2}\right)$, and the effect size $\mathrm{f}^{2}[94,105,113-115]$. A $\mathrm{f}^{2}$ above $0.02,0.15$, or 0.35 is considered a small, medium, or large effect respectively [116]. In addition, in this stage, the direct and indirect effects were analysed in order to verify the multiple mediation model.

By means of running a bootstrapping procedure, the value of the $t$ statistic was determined, and it was compared with its empirical values to analyse the statistical significance of hypothetical relationships. We can see the direct effect as well as the indirect effects with their respective $t$ - and $p$-values. These determine statistical significance. The $t$-value is another way of determining the significance of a coefficient by analysing the critical value against the empirical value. The critical values for one-tailed test are 1.28 (significance level $=10 \%), 1.65$ (significance level $=5 \%$ ), 2.33 (significance level $=1 \%$ ) [112]. Given this, the results are within the critical values established for one-tailed test with a significance level of $5 \%$. These parameters determined the existence of mediation. Likewise, we analysed the confidence intervals that allow us to verify if a path coefficient is significantly different from zero, as another way to assess the significance.

Table 6 and Figure 2 show the results of the structural model, where direct and indirect effects are also shown and where the decision is to determine whether the hypotheses are supported or not by the model. In general terms, mediation occurs when the relationship between the exogenous variable $(\mathrm{x})$ and the endogenous variable $(\mathrm{y})$ changes as a result of the inclusion of a mediator variable [94]. According to our findings, the mediating effect of shared knowledge and organisational commitment in the relationship between organisational values and collaborative public management is confirmed, in correspondence with the theoretical argumentation of Nitzl et al. [117]. 
Table 6. Structural model: hypotheses test result.

\begin{tabular}{|c|c|c|c|c|c|c|}
\hline Direct Effects & Path Coefficients & 95\% BCa Confidence Intervals & $t$-Value & $p$-Value & $\mathrm{f}^{2}$ & Support \\
\hline $\mathrm{SK} \longrightarrow \mathrm{CPM}$ & $0.251^{* *}$ & {$[0.036,0.470]$} & 1.883 & 0.030 & 0.041 & \\
\hline $\mathrm{OC} \longrightarrow \mathrm{CPM}$ & $0.257^{* *}$ & {$[-0.002,0.480]$} & 1.756 & 0.040 & 0.044 & \\
\hline $\mathrm{OV} \longrightarrow \mathrm{CPM}$ & $0.152^{* * *}$ & {$[-0.076,0.426]$} & 0.993 & 0.160 & 0.012 & No $(\mathrm{H} 1)$ \\
\hline $\mathrm{OV} \longrightarrow \mathrm{SK}$ & $0.742^{* * *}$ & {$[0.677,0.811]$} & 17.952 & 0.000 & 1.227 & \\
\hline $\mathrm{OV} \longrightarrow \mathrm{OC}$ & $0.736^{* * *}$ & {$[0.650,0.809]$} & 14.965 & 0.000 & 1.164 & \\
\hline Indirect Effects & Path Coefficients & 95\% BCa Confidence Intervals & $t$-Value & $p$-Value & $\mathbf{f}^{2}$ & Support \\
\hline $\mathrm{OV} \longrightarrow \mathrm{SK} \longrightarrow \mathrm{CPM}$ & $0.186^{* *}$ & {$[0.027,0.352]$} & 1.871 & 0.031 & N.A. & Yes $(\mathrm{H} 2)$ \\
\hline $\mathrm{OV} \longrightarrow \mathrm{OC} \longrightarrow \mathrm{CPM}$ & $0.189^{* *}$ & {$[0.001,0.356]$} & 1.736 & 0.041 & N.A. & Yes (H3) \\
\hline
\end{tabular}

Notes: BCa: Bias Corrected and Accelerated Bootstrap, ${ }^{*} \mathrm{t}(0.10,4999=1.28),{ }^{* *} \mathrm{t}(0.05,4999=1.65),{ }^{* * *} \mathrm{t}(0.01,4999=2.33) .{ }^{*} p<0.10$,

${ }^{* *} p<0.05,{ }^{* * *} p<0.01$, one-tailed test.

Therefore, organisational values showed a direct, but not significant, relationship with collaborative public management $(\beta=0.152, p>0.05)$, and thus did not support hypothesis H1. Regarding shared knowledge and organisational commitment as mediating variables in the relationship between organisational values and collaborative public management, our results showed significant indirect effects $(B=0.186, p<0.05 ; \beta=0.189, p<0.05)$ that support hypotheses $\mathrm{H} 2$ and $\mathrm{H} 3$. In addition, the model showed the values of $\mathrm{R}^{2}(0.551$, 0.538 , and 0.351 ) of the latent endogenous constructs, in such a way that, the higher the value of $\mathrm{R}^{2}$, the greater the predictive capacity. On the other hand, Falk and Miller [118] consider that a $\mathrm{R}^{2}$ must have a minimum value of 0.10 ; Chin [119] considers $0.67,0.33$, and 0.10 (substantial, moderate, and weak, respectively); while Hair et al. [94] recommend 0.75, 0.50 , and 0.25 (substantial, moderate, and weak, respectively). Although the objective of PLS-SEM is to maximise the explained variance $\left(\mathrm{R}^{2}\right)$ of the endogenous latent variables in the path model, the results obtained in this study showed a moderate $\mathrm{R}^{2}$ predictive power.

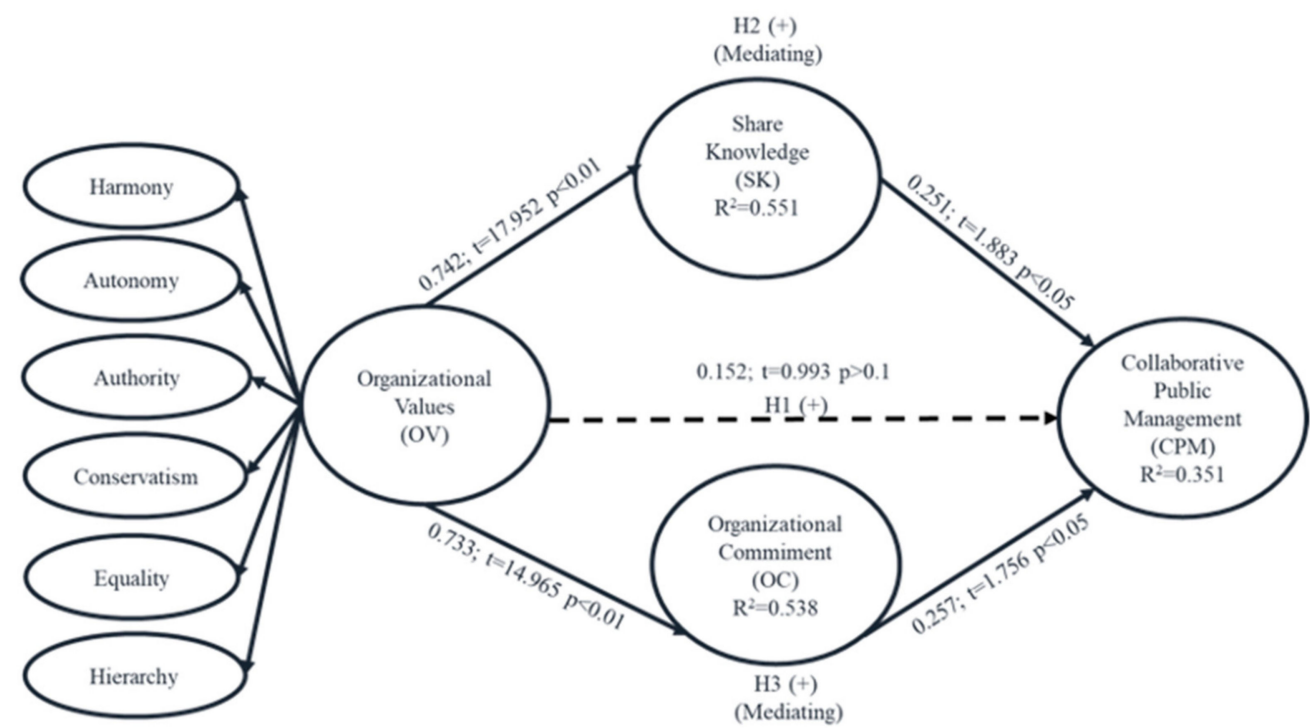

Figure 2. Theoretical model estimation.

\subsection{Type of Mediation and Magnitude}

According to Cepeda-Carrion et al. [120], to estimate the type of mediation, it is necessary to identify the significance of the mediation effects as well as the type of mediation and its magnitude. Therefore, if the direct effect is not significant and the indirect effects are significant, it is considered that there is complete or full mediation. In this case, a multiple 
full mediation was observed, since the direct effect of the construct "organisational values" on "collaborative public management" was not significant, while the indirect effects of mediation were significant. These results provide empirical evidence that "shared knowledge" and "organisational commitment" mediate the relationship between "organisational values" and "collaborative public management".

\section{Discussion and Conclusions}

Public sector organisations need to look for alternatives that allow them to achieve greater efficiency in management, and collaborative public management is an option whereby it can be achieved through the interdependence and collaboration between public organisations. Our findings provide empirical evidence that shared knowledge and organisational commitment mediate the relationship between organisational values and collaborative public management. Likewise, our results showed a non-significant direct effect of organisational values on collaborative public management, as well as significant indirect effects of the mediating variables, which are supported by the Theory of Resources and Capacities and, more specifically, in the perspective based on the knowledge.

Therefore, to make collaborative public management more efficient, knowledge management strategies must be incorporated and implemented, in addition to designing practices aimed at retaining employees who are committed to the organisation. These skills can be developed through organisational rules and values [121-123]. Furthermore, these results are consistent with Anvari et al. [124], who suggest that shared knowledge and organisational commitment are mediator variables.

The results of the empirical model theoretically support the foundation so that the directors of collaborative public management can strengthen and seek out areas of opportunity for better and more effective management. Thus, the improvement and effectiveness of the organisation derive, amongst other things, from short- and medium-term strategies of knowledge management practices and sharing this knowledge, and hence building organisational competencies through strategic knowledge. For knowledge management strategies to be implemented in public organisations, two elements are usually required: the willingness of individuals, groups, and managers, as well as the organisational commitment to transfer this knowledge for their mutual benefit.

In short, from the perspective of such theory, the contribution of this paper is to provide evidence of the importance of intangible internal resources which can generate value for collaborative public management in emerging economies. According to Bansal [49], organisational values are strategic resources and form part of organisational culture. Knowledge, on the other hand, has become the most important and essential resource for creating value in organisations $[42,53,55]$. In contrast, organisational engagement is linked to organisational effectiveness in the public sector in terms of organisational results [125].

Our findings provide empirical support for this multiple mediating role. More specifically, "shared knowledge" and "organisational commitment" represent a mechanism that underlies the relationship between "organisational values" and "collaborative public management". A predicted "cause and effect" relationship cannot be "real" effect, owing to the fact that an influence (i.e., mediator) can describe the entire nature of the relationship [94].

The main conclusion of this paper is that the findings are in line with the theory. That is, organisational commitment and shared knowledge mediate the relationship between organisational values and collaborative public management. This means that there are two mediating variables that explain the relationship between organisational values and collaborative public management. The larger the extent to which organisational values are promoted and managed as strategic resources, the stronger organisational commitment will be, and the more knowledge will be shared. In real terms, a change in the construct of organisational values causes changes in the mediating variables, which, in turn, causes a change in collaborative public management. In this way, mediating variables determine the nature of the relationship between the independent and dependent constructs. Consequently, as one of the main characteristics by adopting the PLS-SEM in order to guarantee 
the reliability, and convergent and discriminant validity, through the most recent statistics (HTMT), as well as to avoid multicollinearity and bias, the results obtained, applying this methodology, are robust $[126,127]$.

The results of this research could contribute to good public governance, which, aligned with the European 2020 Strategy for Good Governance as a strategical resource, can be observed in practice and results. In this regard, Noja et al. [128] analysed the impact of public management in relation to economic and social development, which is based on data from 1995 to 2017 in the European Union, ultimately considering that public governance requires an additional effort and more attention, as well as a highly topical issue to achieve greater efficiency in its measures. This is due to the fact that good public governance should support the development in an economic and social level. In this context, Triantafillou et al. [129] argue that a good government refers to the governance potential to achieve greater good. Furthermore, public governance is not concerned with market competition, it is rather with the need to work collaboratively, as well as participating quickly to find the correct solution at both the community and society levels. As a result of it, modern organisations have to survive in a rapidly changing, challenging environment, and take quick decisions to solve problems [130]. Nowadays, the Mexican government faces large challenges in the face of the COVID-19 pandemic, not just in terms of the economy, but also in terms of many social aspects.

In addition, the study has the following evidence for the practice:

- The empirical evidence shows that, in general, collaborative public management generates efficiency and effectiveness for the benefit of the users of the public service.

- If governments share tangible and intangible resources, they could solve the citizens' problems more quickly.

- Impulse organisational values, shared knowledge, and organisational commitment within the organisation generates value in the collaborative public management.

- Knowledge of the factors that determine collaborative public management and shared knowledge, as well as its disclosure, are key drivers for strengthening cooperative links so that more effective actions can be taken to overcome threats affecting the economy and society in general (for example, as response to the COVID-19 pandemic).

- Emphasising the importance of intangible internal resources contributes to the awareness concerning the value of collaborative public management in emerging economies.

\section{Limitations and Directions for Future Research}

Despite notable strengths, this research presents some limitations. Firstly, the sample size was relatively small, which advises caution in making generalisations from the results. Secondly, a non-experimental cross-sectional research design or transversal type is used, which implies that data collection was carried out in a single period of time, and a longitudinal or evolutionary study is recommended. Thirdly, as for the context of application, it would be convenient to test the theoretical model in other federal entities of the public sector that would allow us to verify the findings of this study with those found in other contexts and countries. Another limitation of this research is that no account was taken of the variable of retention rates of committed employees. This could be studied in future research. Knowledge retention when employees leave the organisation and control variables could have been studied also. These help to explain, for instance, whether or not the income for civil servant jobs has any influence on the variables studied.

Author Contributions: Conceptualization, J.J.G.-M. and M.M.A.; Data collection, E.F.M. and M.M.A.; Formal analysis, J.J.G.-M. and M.M.A.; Investigation, J.J.G.-M. and M.M.A.; Methodology, J.J.G.M. and M.M.A.; Supervision, J.J.G.-M.; Validation, J.J.G.-M.; Writing-original draft, J.J.G.-M. and M.M.A.; Writing-review \& editing, J.J.G.-M. All authors have read and agreed to the published version of the manuscript.

Funding: This research received no external funding.

Institutional Review Board Statement: Not applicable. 
Informed Consent Statement: Not applicable.

Data Availability Statement: Restrictions apply to the availability of this data.

Acknowledgments: The authors are thankful to the Mexican public servants and institutions for answering the survey.

Conflicts of Interest: The authors declare not to have any conflict of interest.

\section{References}

1. Daft, R.L. Teoría y Diseño Organizacional; Cengage Learning, Inc.: Boston, MA, USA, 2019.

2. Wood, D.; Gray, B. Toward a comprehensive theory of collaboration. J. Appl. Behav. Sci. 1991, 27, 139-162. [CrossRef]

3. Eriksson, E.; Andersson, T.; Hellström, A.; Gadolin, C.; Lifvergren, S. Collaborative public management: Coordinated value propositions among public service organizations. Public Manag. Rev. 2019, 21, 1-23. [CrossRef]

4. Penrose, E. The Theory of the Growth of the Firm; Blackwell: Oxford, UK, 1959.

5. Wernerfelt, B.A. Resource-based view of the firm. Strateg. Manag. J. 1984, 5, 171-180. [CrossRef]

6. Barney, J. Firm resources and sustained competitive advantage. J. Manag. 1991, 17, 99-120. [CrossRef]

7. Grant, R.M. Toward a knowledge-based theory of the firms. Strateg. Manag. J. 1996, 117, 109-122. [CrossRef]

8. Conner, K.; Prahalad, C.K. A Resource-Based Theory of the Firm: Knowledge versus Opportunism. Organ. Sci. 1996, 7, 477-501. [CrossRef]

9. Kogut, B.; Zander, U. Knowledge of the firm, combinative capabilities, and the replication of technology. Organ. Sci. 1992, 3 , 383-397. [CrossRef]

10. Min-Seok, P. IT governance and business value in the public sector organizations. The role of elected representatives in IT governance and its impact on IT value in U.S. state governments. Decis. Support Syst. 2014, 59, 274-285. [CrossRef]

11. Vigoda-Gadot, E.; Meiri, S. New Public Management Values and Person-Organization Fit: A Socio-Psychological Approach and Empirical Examination among Public Sector Personnel. Public Adm. 2008, 86, 111-131. [CrossRef]

12. Khanna, T.; Palepu, K. Winning in Emerging Markets: A Road Map for Strategy and Execution; Harvard Business Press: Cambridge, MA, USA, 2010.

13. Lazzarini, L. Young Iberoamerican scholars leveraging the competitive advantage of Iberoamerican scholars. Manag. Res. J. Iberoam. Acad. Manag. 2012, 10, 64-73.

14. Vassolo, R.S.; De Castro, J.; Gomez-Mejia, L.R. Managing in Latin America: Common issues and a research agenda. Acad. Manag. Perspect. 2011, 25, 22-36. [CrossRef]

15. Grant, R.M. The Resource-Based Theory of Competitive Advantage: Implications for Strategy Formulation. Calif. Manag. Rev. 1991, 33, 114-135. [CrossRef]

16. Teece, D.G.; Pisano, G.; Shuen, A. Dynamic capabilities and strategic management. Strateg. Manag. 1997, 18, 509-533. [CrossRef]

17. Grant, R.M. A Knowledge Accessing Theory of Strategic Alliances. J. Manag. Stud. 2004, 41, 61-64. [CrossRef]

18. Lee, J.; Lee, J. Seeds of Distrust: Conflicts over Sustainable Development in a Local Fracking Policy Network in New York State. Public Manag. Rev. 2018, 20, 108-135. [CrossRef]

19. Osborne, S. From Public Service-Dominant Logic to Public Service Logic: ¿Are Public Service Organizations Capable of CoProduction and Value Co-Creation? Public Manag. Rev. 2018, 20, 225-231. [CrossRef]

20. Hughes, O.E. Public Management and Administration. An introduction; Plagrave Macmillan: New York, NY, USA, 2012.

21. Robinson, M. Global Centre for Public Service Excellence; From Old Public Administration to the New Public Service Implications for Public Sector Reform in Developing Countries, UNDP: Singapore, 2015.

22. Raczkowski, K. Public Management. Theory and Practice; Springer International Publishing: Cham, Switzerland, 2016.

23. Peters, G.B.; Pierre, J. Governance without Government? Rethinking Public Administration. J. Public Adm. Res. Theor. 1998, 8 , 223-243. [CrossRef]

24. McGuirre, M. Collaborative Public Management: Assessing What We Know and How We Know It. Public Adm. Rev. 2006, 66, 33-43. [CrossRef]

25. Uvalle, R. El valor institucional de la gestión pública. Rev. Venez. De Gerenc. 2004, 9, 1-29.

26. Uvalle, R. Desafíos de la Administración Pública Contemporánea. Rev. De Adm. Pública 2008, XLIII, 11-30.

27. O'Leary, R.; Bingham, L.B. The Collaborative Public Manager. New Ideas for the Twenty-First Century; Georgetown University Press: Washington, DC, USA, 2009.

28. Ansell, C.; Gash, A. Collaborative Governance in Theory and Practice. J. Publ. Adm. Res. Theor. 2007, 18, 543-571. [CrossRef]

29. Agranoff, R.; McGuirre, M. Collaborative Public Management; Georgetown University Press: Washington, DC, USA, 2003.

30. Kapucu, N.; Yuldashev, F.; Bakiev, E. Collaborative Public Management and Collaborative Governance: Conceptual Similarities and Differences. Eur. J. Econ. Political Stud. 2009, 2, 39-60.

31. Dermol, V.; Surca, N.T. Communication, company mission, organizational values, and company performance. Soc. Behav. Sci. 2018, 238, 542-551. [CrossRef]

32. Gibb, S.; Burns, C. Organizational Values: Positive, Ambivalent and Negative Interrelations in Work Organizations. J. Hum. Values 2018, 24, 116-126. [CrossRef] 
33. Schneider, B.; Barbera, K.M. The Oxford Handbook of Organizational Climate and Culture; Oxford University Press: New York, NY, USA, 2014.

34. Tamayo, A.; Mendes, A.M.; Torres, M.G.T. Inventario de valores organizaciones. Estud. De Psicol. 2000, 5, 289-315. [CrossRef]

35. Brčić, R.R.; Malbašić, I. Public Management and Organizational Values in Public of Eastern Slavonia. Interdiscip. Manag. Res. 2013, 81, 91 .

36. Seevers, B. Identifying and clarifying organizational values. J. Agric. Educ. 2000, 41, 70-79. [CrossRef]

37. Akinsorotan, A.O.; Oladele, O.I. Organizational values perceived as evident among extension agents of agricultural development programs in Nigeria. Agric. Trop. Subtrop. 2009, 42, 110-117.

38. Porto, J.B.; Ferreira, M.C. A Scale of Organizational Values Framed on Schwartz's Theory of Cultural Values. Psicol. Teoría E Pesqui. 2016, 32, 1-10. [CrossRef]

39. Konishi, E.; Yahiro, M.; Nakajima, N.; Ono, M. The Japanese Value of Harmony and Nursing Ethics. Nurs. Ethics 2009, 16, 625-636. [CrossRef]

40. Varelius, J.; Finland, T. The value of autonomy in medical ethics. Med. Health Care Philos. 2006, 9, 377-388. [CrossRef]

41. Satow, R.L. Value-Rational Authority and Professional Organizations: Weber's Missing Type. Adm. Sci. Q. 1975, $20,526-531$. [CrossRef]

42. Nonaka, I.; Takeuchi, H. The Knowledge-Creating Company: How Japanese Companies Create the Dynamics of Innovation; Oxford University Press: New York, NY, USA, 1995.

43. Ramshida, A.P.; Manikandan, D.K. organizational commitment as a mediator of counterproductive work behavior and organizational culture. Int. J. Soc. Sci. Interdiscip. Res. 2013, 2, 59-69.

44. Barron, K.; Chou, S.Y. Developing Normative Commitment as a Consequence of Receiving Help-The Moderated Mediating Roles of Team-Member Exchange and Individualism/Collectivism: A Multi-level Model. J. Manag. Sci. 2016, 3, 141-158. [CrossRef]

45. Choi, G.; Choi, S. The effect of culture on organizational citizenship behavior, job satisfaction, and organizational commitment: A meta-analysis. Acad. J. 2019, 51, 43-72.

46. Waldo, D. The Administrative State; A Study of the Political Theory of American Public Administration; Holmes and Meir: New York, NY, USA, 1984.

47. DeForest, A. Values in public administration: The role of organizational culture. Int. J. Organ. Theory Behav. 2009, 12, 266-279.

48. Santos, L.S.; Leal, F.G.; Serafim, M.C.; Morales, M.C. Values and public administration: A discussion on rationality and parenthetical attitude. Rev. De Adm. Mackenzie 2018, 19, 1-25. [CrossRef]

49. Bansal, P. The Importance of Individual Concerns and Organizational Values in Responding to National Environmental Issues. Organ. Sci. 2003, 14, 510-527. [CrossRef]

50. Brčić, R.; Malbašić, I.; Posarić, N. Organizational Values and Public Management in Local and Regional Self-Government in the Republic of Croatia. Interdiscip. Manag. Res. 2018, 9, 81-91.

51. Melo, W.F.; Domenico, S.M.R. A influência dos valores organizacionais no desempenho de agências bancárias. Rev. Adm. Contemp. 2012, 16, 137-156. [CrossRef]

52. Stride, H.; Higgs, M. An investigation into the relationship between values and commitment: A study of staff in the U.K. charity sector. Nonprofit Volunt. Sect. Q. 2014, 43, 455-479. [CrossRef]

53. Quinn, J.B. Intelligent Enterprise: A Knowledge and Service-Based Paradigm for Industry; The Free Press: New York, NY, USA, 1992.

54. Reich, R. National Innovation Systems: A Comparative Analysis; Oxford University Press: New York, NY, USA, 1992.

55. Batra, J. Knowledge management: Emerging practices in IT industry in NCR. IUP J. Knowl. Manag. 2010, 8, 57-67.

56. Blomgren, L.; O'Leary, R. Federalist No.51: Is the past relevant to today's collaborative public management. Public Adm. Rev. Spec. Issue 2011, 578-582. [CrossRef]

57. De Angelis, C.T. A Knowledge Management and Organizational Intelligence Model for Public Administration. Int. J. Public Adm. 2013, 36, 807-819. [CrossRef]

58. Hernández, J.L.; Pérez, B. La Gestión del Conocimiento como Estrategia para la Mejora Continua en la Administración Pública Municipal. La Experiencia del H. Ayuntamiento de Navolato. Int. J. Good Conscienc. 2012, 8, 1-14.

59. Birza, M.M. The Level of Knowledge and Implementation of Control / Management Standards in Local Public Administration in Romania. Bull. Transilv. Univ. Brasov. Ser. V Econ. Sci. 2012, 5, 75-82.

60. Savvas, I.; Bassiliades, N. A process-oriented ontology-based knowledge management system for facilitating operational procedures in public administration. Expert Syst. Appl. 2009, 36, 4467-4478. [CrossRef]

61. Peluffo, M.B.; Catalan, E. Introducción a la Gestión del Conocimiento y su Aplicación al Sector Público; Instituto Latinoamericano y del Caribe de Planificación Económica y Social: Santiago de Chile, Chile, 2002.

62. Self, T.B.; Matuszek, T.; Self, D.R.; Schraeder, M. The Weaver's Loom: A Conceptual Framework for Facilitating Transformational Human Resource Management through the Strategic Integration of Knowledge Management and Continuous Improvement. J. Bus. Manag. 2014, 20, 87-104.

63. Pineda, L. Prospectiva estratégica en la gestión del conocimiento: Una propuesta para los grupos de investigación colombianos. Investig. Desarro. 2014, 21, 259-282.

64. Rakowska, A.; Espinosa, S.; Valdés, J. Determinants of organizational for public administration employees: A theoretical model with an international perspective. Make Learn TIIM 2015, s/n, 1693-1701. 
65. Elizur, D.; Koslowsky, M. Values and Organizational Commitment. Int. J. Manpow. 2001, 22, 593-599. [CrossRef]

66. Hunt, S.D.; Wood, V.R.; Chonko, L.B. Corporate Ethical Values and organizational commitment in marketing. J. Mark. 1989, 53, 79-90. [CrossRef]

67. Alford, J. Co-Production, Interdependence and Publicness: Extending public service-dominant logic. Public Manag. Rev. 2015, 18, 673-691. [CrossRef]

68. Marques, I.; Leitao, J.; Carvalho, A.; Pereira, D. Public Administration and Values Oriented to Sustainability: A Systematic Aproach to the Literature. Sustainability 2021, 13, 2566. [CrossRef]

69. Der, Z.V.; De Graaf, G.; Lasthuizen, K. What's valued most? Similarities and differences between the organizational values of the public and private sector. Public Adm. 2008, 86, 465-482.

70. Margerum, R.D. Organizational commitment to Integrated and Collaborative Management: Matching Strategies to Constraints. Environ. Manag. 2001, 28, 421-431. [CrossRef]

71. Luen, T.W.; Al-Hawamdeh, S. Knowledge management in the public sector: Principles and practices in police work. J. Inf. Sci. 2001, 27, 311-318. [CrossRef]

72. Kidron, A. Work Values and organizational commitment. Acad. Manag. J. 2017, 21, 239-247. [CrossRef]

73. Michailova, S.; Minbaeva, D.B. Organizational values and knowledge sharing in multinational corporations: The Danisco case. Int. Bus. Rev. 2012, 21, 59-70. [CrossRef]

74. Chang, W.; Liao, S.; Lee, Y.; Lo, W. Organizational commitment, knowledge sharing and organizational citizenship behaviour: The case of the Taiwanese semiconductor industry. Knowl. Manag. Res. Pract. 2013, 13, 299-310. [CrossRef]

75. Jing-Wen, H.; Yong-Hui, L. The mediating effect of knowledge management on social interaction and innovation performance. Int. J. Manpow. 2009, 30, 285-301. [CrossRef]

76. Nazir, T.; Hussain, S.D.; Zaman, K. Mediating effect of knowledge between participative decision making, transformational leadership and organization performance. J. Manag. Inf. 2014, 1, 1-12. [CrossRef]

77. Al-Matari, E.M.; Bin, O.D. The Mediating Effect of Organizational Commitment on the Relationship between Organizational Culture and Organizational Performance in Public Sector: Evidence form KSA. Int. J. Bus. Manag. Sci. 2017, 7, 67-77.

78. Salkind, N. Encyclopedia of Research Design; Sage: Thousand Oaks, CA, USA, 2010.

79. Van der Stede, W.A.; Mark, Y.S.; Chen, C.X. Assessing the quality of evidence in empirical management accounting research: The case of survey studies. Account. Organ. Soc. 2005, 30, 655-684. [CrossRef]

80. Nitzl, C. The use of partial least squares structural equation modelling (PLS-SEM) in management accounting research: Directions for future theory development. J. Account. Lit. 2016, 37, 19-35. [CrossRef]

81. Lin, H. Knowledge sharing and firm innovation capability: An empirical study. Int. J. Manpow. 2007, 2, 315-332. [CrossRef]

82. Thomson, J.L.; Perry, T.; Miller, K. Conceptualizing and Measuring Collaboration. J. Public Adm. Theor. 2009, 19, 23-56. [CrossRef]

83. Allen, N.; Meyer, J.P. The measurement and normative of affective, continuance and normative commitment to the organization. J. Occup. Psychol. 1990, 63, 1-8. [CrossRef]

84. Wold, H. Partial Least Squares. In Encyclopedia of Statistical Sciences; Kotz, S., Johnson, N.L., Eds.; John Wiley and Sons: New York, NY, USA, 1985; Volume 6, pp. 581-591.

85. Hair, J.F.; Sarstedt, M.; Ringle, C.; Mena, J. An assessment of the use of partial least squares structural equation modeling in marketing research. J. Acad. Mark. Sci. 2012, 40, 414-443. [CrossRef]

86. Sarstedt, M.; Ringle, C.M.; Smith, D.; Reams, R.; Hair, J.F. Partial least squares structural. J. Fam. Bus. Strategy 2014, 5, 105-115. [CrossRef]

87. Dijkstra, T.K.; Henseler, J. Consistent partial least squares path modeling. MIS Q. 2015, 39, 297-316. [CrossRef]

88. Henseler, J. Bridging Design and Behavioral Research with Variance-Based Structural Equation Modeling. J. Advert. 2017, 46, 178-192. [CrossRef]

89. Duarte, P.; Amado, S. Methods for modeling reflective-formative second order constructs in PLS. J. Hosp. Tour. Technol. 2018, 9 , 295-313. [CrossRef]

90. Lohmöller, J.B. Latent Variable Path Modeling with Partial Least Squares; Springer: Berlin/Heidelberg, Germany, 1989 ; p. 284. [CrossRef]

91. Wold, H. Soft Modeling: Intermediate between Traditional Model Building and Data Analysis. Math. Stat. 1982, 6, 333-346.

92. Reinartz, W.J.; Haenlein, M.; Henseler, J. An empirical comparison of the efficacy of covariance-based and variance-based SEM. Int. J. Res. Mark. 2009, 26, 332-344. [CrossRef]

93. Henseler, J.; Hubona, G.; Ray, P.A. Using PLS path modeling in new technology research: Updated guidelines. Ind. Manag. Data Syst. 2016, 116, 2-20. [CrossRef]

94. Hair, J.; Hult, G.T.; Ringle, C.; Sarstedt, M. A Primer on Partial Least Square Structural Equation Modeling (PLS-SEM); Sage: Thousand Oaks, CA, USA, 2017; p. 363.

95. Memon, M.A.; Ting, H.; Ramayaht, T.; Chuah, F.; Cheah, J. A review of the methodological misconceptions and guidelines related to the application of structural equation modeling: A Malaysian scenario. J. Appl. Struct. Equ. 2017, 1, i-xiii. [CrossRef]

96. Roldan, J.L.; Sánchez-Franco, M.J. Variance-Based Structural Equation Modeling for Using Partial Least Squares in Information Systems Research. In Research Methodologies, Innovations and Philosophies in Software Systems Engineering and Information System. 2012. Available online: https:/ / www.igi-global.com/chapter/content/ 63264 (accessed on 30 June 2021). 
97. Cheah, J.H.; Memon, M.A.; Chuah, F.; Ting, H.; Ramayah, T. Assessing Reflective Models in marketing research: A Comparison between PLS and PLSc Estimates. Int. J. Bus. Soc. 2018, 19, 139-160.

98. Hair, J.; Sarsted, M.; Ringle, C.M.; Gudergan, M. Advanced Issues in Partial Least Square Structural Equation Modeling; Sage: Thousand Oaks, CA, USA, 2018; p. 254.

99. Diamantopoulos, A.; Riefler, P.; Roth, K.P. Advancing formative measurement models. J. Bus. Res. 2008, 16, 1203-1218. [CrossRef]

100. Van-Riel, A.C.R.; Henseler, J.; Kemen, I.; Sasovova, Z. Estimating hierarchical constructs using consistent partial least squares. The case of second-order composites of common factors. Ind. Manag. Data Syst. 2017, 117, 459-477. [CrossRef]

101. Polites, G.L.; Roberts, N.; Thatcher, J. Conceptualizing models using multidimensional constructs: A review and guidelines for their use. Eur. J. Inf. Syst. 2012, 21, 22-48. [CrossRef]

102. MacKenzie, S.B.; Podsakoff, P.M.; Jarvis, C.B. The Problem of Measurement Model Misspecification in Behavioral and Organizational Research and some Recommended Solutions. J. Appl. Psychol. 2005, 11, 710-730. [CrossRef] [PubMed]

103. Rigdon, E.E. Structural Equation Modeling: Nontraditional Alternatives. In Encyclopedia of Statistics in Behavioral Science; Everitt, B., Howell, D., Eds.; Wiley \& Son: New York, NY, USA, 2005.

104. Jarvis, C.B.; MacKenzie, S.B.; Podsakoff, P.M. A critical review of construct indicators and measurement model misspecification in marketing and consumer research. J. Consum. Res. 2003, 30, 199-218. [CrossRef]

105. Albort-Morant, G.; Henseler, J.; Cepeda-Carrión, G.; Leal-Rodríguez, A.L. Potential and Realized Absorptive Capacity as Complementary Drivers of Green Product and Process Innovation Performance. Sustainability 2018, 10, 381. [CrossRef]

106. Hu, L.T.; Bentler, P.M. Cutoff criteria for fit indexes in covariance structure analysis: Conventional criteria versus new alternatives. Struct. Equ. Model. A Multidiscip. J. 1999, 6, 1-55. [CrossRef]

107. Dijkstra, T.K.; Henseler, J. Consistent and asymptotically normal PLS estimators for linear structural equations. Comput. Stat. Data Anal. 2015, 1, 10-23. [CrossRef]

108. Fornell, C.; Larcker, D.F. Evaluating Structural Equation Models with Unobservable Variables and Measurement Error. J. Mark. Res. 1981, 18, 39-50. [CrossRef]

109. Henseler, J.; Ringle, C.M.; Sarstedt, M. A new criterion for assessing discriminant validity in variance-based structural equation modeling. J. Acad. Market. Sci. 2015, 43, 115-135. [CrossRef]

110. Hernández-Perlines, F. Entrepreneurial orientation in hotel industry: Multi-group analysis of quality certification. J. Bus. Res. 2016, 69, 4714-4724. [CrossRef]

111. Garcia-Machado, J.J. Assessing a moderating effect and the global fit of a PLS model on online trading. MINIB 2017, 26, 1-34. [CrossRef]

112. Hair, J.; Sarstedt, M.; Ringle, C. Rethinking some of the rethinking of partial least squares. Eur. J. Mark. 2019, 53, 566-584. [CrossRef]

113. Ali, F.; Rasoolimanesh, S.M.; Sarstedt, M.; Ringle, C.M.; Ryu, K. An assessment of the use of partial least squares structural equation modeling (PLS-SEM) in hospitality research. Int. J. Contemp. Hosp. Manag. 2018, 30, 514-538. [CrossRef]

114. Müller, T.; Schuberth, F.; Henseler, J. PLS path modelling a confirmatory approach to study tourist technology and tourist behaviour. J. Hosp. Tour. Technol. 2018, 9, 249-266. [CrossRef]

115. Henseler, J. Partial least squares path modeling: Quo vadis? Qual. Quant. 2018, 52, 1-8. [CrossRef]

116. Cohen, J. Statistical Power Analysis for the Behavioural Sciences, 2nd ed.; New York University: New York, NY, USA, 1988.

117. Nitzl, C.; Roldan, J.L.; Cepeda, G. Mediation analysis in partial least squares path modeling: Helping researchers discuss more sophisticated models. Ind. Manag. Data Syst. 2016, 116, 1849-1864. [CrossRef]

118. Falk, R.; Miller, N.A. Primer for Soft Modeling; The University of Akron Press: Akron, OH, USA, 1992.

119. Chin, W.W. The partial least squares approach to structural modelling. In Modern Methods for Business Research; Marcoulides, G.A., Ed.; Lawrence Eribaum: New York, NY, USA, 1998; pp. 295-336.

120. Cepeda Carrión, G.; Nitzl, C.; Roldán, J.L. Mediation Analyses in Partial Least Squares Structural Equation Modeling. Guidelines and Empirical Examples. In Partial Least Squares Path Modeling; Springer International Publishing: Cham, Switzerland, 2017; pp. 173-195.

121. Metaxiotis, K.; Ergazakis, K.; Psarras, J. Exploring the world of knowledge management: Agreements and disagreements in the academic practitioner community. J. Knowl. Manag. 2005, 9, 6-18. [CrossRef]

122. Chiu, C.N.; Chen, H. The study of knowledge management and organizational effectiveness in Taiwanese public utility: The mediator role organizational commitment. SpringerPlus 2016, 5, 2-34. [CrossRef] [PubMed]

123. Finegan, J.E. The impact person and organizational values on organizational commitment. J. Occup. Organ. Psychol. 2010, 73, 149-169. [CrossRef]

124. Anvari, R.; Abu, N.N.; Aisyah, S.; Binti, R. Mediating Effects of Affective Organizational Commitment and Psychological Contract in the Relationship between Strategic Compensation Practices and Knowledge Sharing. Procedia Soc. Behav. Sci. 2014, 129, 111-118. [CrossRef]

125. Moon, M.J. Organizational Commitment Revisited in New Public Management: Motivation, Organizational Culture, Sector, and Managerial Level. Public Perform. Manag. Rev. 2000, 24, 177-194. [CrossRef]

126. Buitrago, R.E.; Barbosa Camargo, M.I.; Cala Vitery, F. Emerging Economies' Institutional Quality and International Competitiveness: A PLS-SEM Approach. Mathematics 2021, 9, 928. [CrossRef] 
127. Yang, M.; Mamun, A.A.; Mohiuddin, M.; Al-Shami, S.S.A.; Zainol, N.R. Predicting Stock Market Investment Intention and Behavior among Malaysian Working Adults Using Partial Least Squares Structural Equation Modeling. Mathematics 2021, 9, 873. [CrossRef]

128. Noja, G.G.; Cristea, M.; Sirghi, N.; Hategan, C.D.; Anselmi, P. Promoting Good Public Governance and Environmental Support for Sustainable Economic Development. Int. J. Environ. Res. Public Health 2019, 16, 4940. [CrossRef] [PubMed]

129. Triantafillou, P. Trapped in the Complexity Bowl? Public Governance and the Liberal Art of Governing. Trapped in the Complexity Bowl? Public Governance and the Liberal Art of Governing. Int. J. Public Adm. 2019, 43, 1228-1236. [CrossRef]

130. Sulich, A.; Sołoducho-Pelc, L.; Ferasso, M. Management Styles and Decision-Making: Pro-Ecological Strategy Approach. Sustainability 2021, 13, 1604. [CrossRef] 